\title{
O PAPEL DA MULHER POLONESA NA DINÂMICA DA FAMÍLIA TRADICIONAL: COLÔNIA DOM PEDRO II - CAMPO LARGO - PARANÁ
}

\author{
THE POLISH WOMAN'S ROLE IN THE TRADITIONAL FAMILY \\ DYNAMICS: DOM PEDRO II' COLONY IN CAMPO LARGO - PARANÁ
}

\author{
Mafalda Ales Sikora' \\ Maclovia Corrêa da Silva ${ }^{2}$ \\ Décio Estevão do Nascimento ${ }^{3}$
}

\section{Resumo}

O presente artigo discute o trabalho da mulher polonesa imigrante nas dinâmicas da família tradicional da comunidade da Colônia Dom Pedro II - em Campo Largo. Seu papel como preservadora de conhecimentos e saberes ancestrais foi reproduzido e se propagou ainda que vivendo em terra estrangeira. Utiliza-se a perspectiva socio-histórica para estudar a imigração polonesa, ocorrida no final do século XIX e durante o século XX, para compreender os papéis da mulher polonesa e suas contribuições na formação da família, na alimentação, na difusão de técnicas de trabalho, e na manutenção de costumes ancestrais que constituem aspectos da cultura de sua nação de origem. Enfatiza-se a importância das diferentes funções da mulher na comunidade, que são pouco valorizadas pela sociedade industrial, mas que foram fundamentais para a prosperidade da Colônia.

Palavras chave: mulher polonesa, trabalho, saberes, cultura, técnicas.

\section{Abstract}

This paper develops a discussion about the Polish immigrant woman's work. She was inserted in the community traditional family dynamics of the Cologne Dom Pedro II. Her role in the preservation of ancestral knowledge was reproduced and spread, even though living in a foreign land. It is used a socio-historical perspective to study the Polish immigration that occurred in the late nineteenth century and during the twentieth century to understand the roles of women and their contributions to the Polish family formation, in food, in the dissemination of technical work, and maintenance of ancient customs which are culture aspects of their origin nation. It is emphasized the importance of woman's different roles that are undervalued by the industrial society, but were vital for the Colony's prosperity.

Key-words: Polish woman, work, knowledge, culture techniques.

1 Graduação, Bacharel em Serviço Social - Pós Graduação em Metodologia Cientifica e Gestão em Políticas Sociais e Publicas - Professora do Curso de Graduação em Serviço Social das Faculdades Integradas "Espírita" - Aluna do Curso de Mestrado do Programa de Pós-Graduação em Tecnologia da Universidade Tecnológica Federal do Paraná - mafasikora@yahoo.com.br

2 Professora do Programa de Pós-Graduação em Tecnologia da Universidade Tecnológica Federal do Paraná - Doutora em Estruturas Ambientais Urbanas pela Faculdade de Arquitetura e Urbanismo da Universidade de São Paulo - macloviasilva@utfpr.edu.br

3 Professor do Programa de Pós-Graduação em Tecnologia da Universidade Tecnológica Federal do Paraná - Doutor em Ciências do Homem e Tecnologia pela Université de Technologie de Compiègne, UTC, França-decio@utfpr.edu.br 


\section{Introdução}

No final do século XIX, os Poloneses chegaram ao Paraná e se instalaram na Colônia Dom Pedro II no Município de Campo Largo. Este movimento fazia parte das políticas nacionais de imigração. As terras da Colônia, emancipada em 1878, foram compradas pelo então imperador do Brasil, Dom Pedro II, para serem vendidas ou doadas para os estrangeiros interessados em trabalhar no território brasileiro (WACHOWICZ, 1976).

Estanislau Bilinoski (1997/2008), em depoimento, explicou sobre as primeiras famílias que habitaram a Colônia Dom Pedro II. Segundo ele, elas procediam do estado de Santa Catarina, onde haviam feito tentativas de se instalar em terras que já eram habitadas por povos indígenas. O contexto histórico nacional era complexo, com fatos marcantes que transformavam o país: a vinda da família real para a cidade do Rio de Janeiro em 1808, a Independência do Brasil com relação a Portugal em 1822, a criação da Lei Eusébio de Queirós de 1850 que proibia o tráfico negreiro, a primeira Lei de Terras de 1850, a abolição da escravatura em 1888, e a proclamação do regime republicano em 1889.

Estas mudanças na política socioeconômica transformaram a estrutura da oligarquia latifundiária, voltada para um modelo de agro-exportação. Paulatinamente foram escasseando mão-de-obra para a agricultura, fosse ela latifundiária ou de subsistência (WACHOVICZ, 1976).

Então, eram "fortes" as razões para o Brasil, e o Paraná, investirem nas parcas estruturas para estabelecer processos imigratórios, que muitas vezes, reduziam-se a compra de terras. Do outro lado do oceano, os países europeus enfrentavam uma crise socioeconômica. Autores como Wachowicz (1976, 1981) e Boschilia (2004) apresentam situações da imigração polonesa iniciada no final do século XIX, e nas primeiras décadas do século XX, que podem justificar as razões de tão longos deslocamentos humanos. A Polônia estava dominada por outros países, com batalhas e conflitos de terra, com repressões e opressões ideológicas, carência de postos de trabalho, poucos e investimentos na agricultura.

Mas, as lutas dos imigrantes continuaram no Brasil. Os núcleos criados exigiam esforços no sentido de preparar a terra para a agricultura de subsistência, os instrumentos de trabalho precisavam ser adaptados e criados, e muitas técnicas necessitavam de materiais que não existiam localmente. Dentre as principais conquistas, estavam o artesanato, a moagem de cereais, a marcenaria, a ferraria e a olaria. As famílias eram numerosas, e cabia a mulher a grande responsabilidade sobre a educação, as artes, a alimentação e o vestuário (WACHOWICZ, 1976).

Os chefes das famílias eram responsáveis pela mulher, filhos e empregados. A mulher polonesa desempenhava um papel importante, pois seu trabalho, além das responsabilidades do lar, com atividades domésticas, estendia-se para as atividades agrícolas de subsistência. Ela possuía saberes diversos, os quais eram repassados às gerações. Além disso, ela trazia na sua formação a tradição de práticas ancestrais como os traços da cultura e tradição polonesa. 
O objetivo deste artigo é discutir aspectos do trabalho da mulher polonesa na dinâmica da família tradicional da comunidade da Colônia Dom Pedro II - Campo Largo que permitiram a reprodução e a permanência de saberes culturais da tradição ancestral polonesa, fundamentais para o sucesso dos sonhos de progresso e felicidade. Ainda que estivessem vivendo em outro país, esses saberes influenciavam o agir no contexto social e familiar dos descendentes. No desenvolvimento da pesquisa, de natureza bibliográfica e qualitativa, foram aplicados instrumentos metodológicos como observações e depoimentos "in loco" para a coleta de dados.

\section{A família tradicional no contexto da Colônia - Dom Pedro II}

Identifica-se na evolução da existência humana a estruturação de núcleos familiares que passaram por diferentes ciclos com base em vários aspectos, como por exemplo, o religioso, o econômico, o moral e o jurídico. Constata-se que mesmo quando o núcleo familiar foi alvo de singulares modificações no processo histórico, muitos deles conseguiram manter suas características e sobreviveram às influências dos processos adaptativos, mantendo a perpetuação e funcionalidade de seus hábitos e costumes por vários séculos (BARROS, 2001).

A família tradicional da Colônia Dom Pedro Il conduzia a sua vida com as bases da cultura dos ancestrais poloneses influenciadas pelo modelo de família cristã. Era uma pequena sociedade, cujos membros tinham contato direto, laços emocionais e uma história de vida. Estava em constante transformação, pois interagia com o contexto social e passava por vários momentos de integração. Entre os séculos XVIII e XIX, as revoluções políticas, sociais e econômicas articularam transformações na sociedade europeia, dentre elas a consolidação da família burguesa. Ela passou a ser um padrão a ser reproduzido (GALANO, 2006).

No Brasil, não foi diferente. A história das elites da família brasileira foi marcada pelos interesses em fazer circular as ideias de consumo e comportamento dos países desenvolvidos. A família tradicional era estruturada de forma nuclear, composta por pai, mãe, filhos e agregados e esteve centrada na ordem patriarcal legitimada pela religião cristã ocidental, cujo poder emanava do patriarca (BARROS 2001).

"Historicamente, a origem da família no mundo ocidental fundamenta-se no modelo tradicional da família Romana, Cristã, em que o marido era o chefe, com poder incontestável, sobre todos os membros componentes, esposa, filhos, filhas e os agregados" (CANEZIN, 2004, p. 146). Com base nesse modelo de família tradicional que a Comunidade polonesa conduziu a sua vida em sociedade. A família polonesa da Colônia Dom Pedro II, desde a sua imigração, final do século XIX e durante o século XX se caracterizava como família tradicional, patriarcal e monogâmica, composta pelo pai, mãe, filhos e agregados. Havia na figura do pai, o patriarca, chefe de família, cujo respeito e obediência caracterizavam o poder e responsabilidade 
pela família. E sob o jugo do chefe familiar, se mantinham unidos, na casa, na igreja, nas comemorações e nas atividades agrícolas. Os filhos auxiliavam os pais e agregados no trabalho doméstico ou na lavoura. Como a família se constituía uma unidade social, os filhos participavam de todas as atividades da Colônia.

Na família tradicional, as uniões matrimoniais frequentemente procediam de determinações dos pais, os quais, muitas vezes, combinavam o casamento sem consultar os filhos. Não era do conhecimento da jovem mulher que ela estava assumindo um novo compromisso familiar que implicava em conviver com uma nova pessoa e trabalhar para um novo empreendimento. O futuro marido podia aparecer pela primeira vez para a jovem no dia do noivado, um compromisso que antecedia o matrimônio. Certamente muitos interesses giravam entre as famílias contratantes, sobretudo aqueles de natureza socioeconômica e cultural - posses de terra, renome social, afinidades, e amizades. Todavia, seria importante considerar que "a família, [...]. tem papel fundamental no desenvolvimento da socialização e da afetividade. [...] ela não é somente uma rede de relações, mas também é uma união de papéis que devem ser trabalhados dentro da convivência social dos indivíduos" (MIOTO, 1997, p.120). Essa concepção de família se fundamenta na ideologia tradicional, e conforme Barros,

o elemento basilar da sociedade não é o indivíduo, mas sim a entidade familiar monogâmica, parental, patriarcal, Isto é, a tradicional família romana, que veio a ser recepcionada pelo cristianismo medieval, que reduziu a entidade familiar à família nuclear e consagrou como família-modelo a Sagrada Família: pai (José). Mãe (Maria) e filho (Jesus) (BARROS, 2001, p.8).

A constituição familiar tradicional, embora tenha seus fundamentos no modelo Romano desde a ldade Média, está marcada por características que se sustentaram por séculos. O matrimônio e o patrimônio somaram-se a forma de sacramentalização, e a união passou a se constituir no compromisso social e religioso da família. "O matrimônio, sem nada perder da sua carga patrimonial, foi transformado em sacramento, ao lado do batismo, crisma, confissão, comunhão, extrema-unção e outros atos" (BARROS, 2001 p.10).

A concepção patriarcal de família se traduz em uma estrutura familiar dominada pelo varão, que mantinha o poder sob o seu jugo, incluindo a mulher, cuja virtude monogâmica era mantida pelo poder da submissão marital. Desta forma, o casamento na estrutura familiar exerceu o papel fundamental na formação das relações familiares, constituído pela segurança de reprodução cultural originando-se a divisão de papeis entre o marido e a mulher. Dessa divisão de tarefas entre o marido e mulher nasceram as funções sociais definidas entre o patrimônio e o matrimônio (BARROS, 2001). Para Pereira (1997), o casamento era uma "instituição matrimonializada, patrimonializada, patriarcal, hierarquizada e heterossexual, onde a mulher era considerada relativamente incapaz para exercer certos atos da vida civil" o 
que a colocava em uma posição inexplicável de dependência e inferioridade perante o esposo (PEREIRA, 1997, apud CANEZIN, 2004, p.147).

Considerando que a concepção da família tradicional era aprovada pela igreja católica, pode-se afirmar que ela teve bases para reproduzirse durante séculos a sujeição da mulher ao homem, estando descrita em várias encíclicas papais como na Rerum Novarum, de Leão XIII, publicada em 1891: "à mulher, a qual, por natureza, destina-se, de preferência, aos arranjos domésticos que, de outro lado, salvaguardam admiravelmente a honestidade sexual, correspondendo melhor, pela própria natureza, ao que pede a boa educação e a prosperidade da família" (LEÃO XIII, 1.891, apud CANEZIN, 2004, p. 144).

Este quadro caracteriza os modos de vida nas famílias da Colônia Dom Pedro II, caracterizadas pelos ensinamentos conservadores da cultura polonesa, complementados pelas orientações da igreja Católica Romana. Lopes Praça, (Castro, 2000), monarca liberal, foi o primeiro autor português a defender a liberdade industrial e o acesso ao ensino secundário para a mulher. Porém,

As primeiras preocupações com a educação da mulher tinham a ver com o seu papel na família, sobretudo enquanto mãe (primeira educadora dos filhos), enquanto esposa (capaz de acompanhar o marido numa festa, numa conversa) e enquanto dona de casa (capaz de gerir com sobriedade os bens da família, de administrar e construir o bem-estar dentro de casa) (CASTRO, 2000, p. 114).

A maternidade e o trabalho tinham um papel fundamental na missão da mulher. Este aspecto era reforçado subjetivamente pelas homilias dominicais da igreja, em que se reafirmava a manutenção do papel da mulher perante a família e a sociedade, assegurando-se a moral e os bons costumes. A preocupação da igreja pode ser esclarecida pela posição do Papa Pio XII em 1943, quando reforçou que a mulher pela sua própria natureza tinha o dever da maternidade, da família e ser parceira do marido. Para a igreja católica, ela

colabora com o homem, mas no modo que lhe é próprio, segundo sua natural tendência. Ora, o ofício da muIher, sua maneira, sua inclinação inata, é a maternidade. Toda a mulher é destinada para ser mãe: mãe no sentido físico da palavra ou num significado mais espiritual e elevado, mas não menos real (PAPA PIO XII, 1.943, apud CANEZIN, 2004, p. 144).

Um argumento bastante enfático era que o matrimônio representava segurança e proteção para a mulher, e os padres procuravam citar nas suas pregações exemplos de mulheres que viviam fora dos padrões sociais estabelecidos e não eram "felizes". Mas, elas precisavam oficializar seus papéis por meio dos sacramentos. Ressaltava-se a o compromisso e o convívio sacramentado. "A legislação civil e religiosa só reconhecia o estatuto social da mulher casada e mãe" (DEL PRIORE, 1993. p. 50). 
Nos países em que dominou o pensamento cristão, a família teve bases monogâmicas, que "é o modo de união conjugal mais puro, mais conforme os fins culturais da sociedade e mais apropriados à conservação individual, tanto para os cônjuges como para a prole" (MONTEIRO, 2001, p.54).

Ao viver nesta modalidade de família tradicional, cuja base se centrava nos ensinamentos da igreja, a mulher era vista como um ser inferior, frágil, cujo estigma configurava baixa inteligência e incapacidade racional. A sua realização se dava pelas atividades de casamento, maternidade e o trabalho doméstico. Submetia-se a essa condição de vida, sempre sob a atenção e autoridade do marido. Sua educação restringia-se às atividades domésticas, à prática da virtude e da obediência ao esposo reproduzindo padrões de comportamentos herdados culturalmente e que eram repassados a outras gerações.

A vida feminina estava restrita "ao bom desempenho do governo doméstico e na assistência moral à família, fortalecendo seus laços" (SAMARA, 1983, p. 59). Esse sistema estabelecia os papéis sociais definidos para o homem e para a mulher no contexto familiar e social.

\section{Os saberes, os (a)fazeres e a família}

A ordem patriarcal legitimada pela religião cristã ocidental, também estava marcada pelo silêncio, que configurava um comportamento típico da subordinação e dependência ao pai ou marido. Havia também a noção de "propriedade" no seio familiar, fundamentado pelas leis públicas. O Código Civil de 1916 assentava-se no princípio da "preponderância do homem sobre a mulher na sociedade conjugal e na afirmação do seu poder marital e paterno, como fortalecimento do modelo hierarquizante da família patriarcal" (RAUPP, 1996, p. 41).

Apoiado sobre três pilares, a família, a propriedade e o contrato, Código Civil de 1916 apresentava uma família com caráter econômico, hierarquizada e patriarcal, comandada pela figura masculina, ficando à margem a figura da esposa, que era tratada como um ser incapaz, subjugada aos ditames do chefe da união. O casamento foi indissolúvel entre 1916 e 1977 (Lei $n^{\circ}$ 6.515/77) (DALL'ALBA, 2012).

No capítulo 1, "Das pessoas naturais", do Código Civil dos Estados Unidos do Brasil, regido pela lei $n^{\circ} 3.071$, de $1^{\circ}$ de janeiro de 1916, apresenta-se uma pequena diferença de interpretação entre ser "totalmente" incapaz e ser "relativamente "incapaz, que era o caso das mulheres casadas". Ou seja, se ela não casasse, pode-se concluir que ela seria sempre um ser capaz de exercer os "certos" direitos da vida dita "civil", como se lê nos dois artigos abaixo.

Art. 5. São absolutamente incapazes de exercer pessoalmente os atos da vida civil:

I. Os menores de dezesseis anos. 
II. Os loucos de todo o gênero.

III. Os surdos-mudos, que não puderem exprimir a sua vontade.

IV. Os ausentes, declarados tais por ato do juiz.

Art. 6. São incapazes, relativamente a certos atos (art.

147, n. 1), ou à maneira de os exercer:

I. Os maiores de dezesseis e menores de vinte e um anos (arts. 154 a 156).

II. As mulheres casadas, enquanto subsistir a sociedade conjugal.

III. Os pródigos.

IV. Os silvícolas (BRASIL, 2012).

Somente na Constituição de 1988, é que homens e mulheres passaram a ter direitos e deveres iguais na sociedade conjugal. No capítulo VII, o artigo § $5^{\circ}$ diz que "os direitos e deveres referentes à sociedade conjugal são exercidos igualmente pelo homem e pela mulher" (BRASIL, 2011).

Com base na concepção de família tradicional de sistema patriarcal, a mulher polonesa da Colônia Dom Pedro II, no final séc. XIX e inicio do séc. $X X$, já se constituía parte integrante do jugo da submissão do patriarca, pai ou marido, o qual interferia "indiretamente" na forma como conduzia em casa hábitos culturais, religiosos, alimentícios, desenvolvimento de habilidades manuais e a reprodução de saberes e práticas das tradições ancestrais originadas na Polônia.

Os saberes e técnicas constituídas pelos costumes, tradições culturais, formavam a identidade cultural do povoado. A realidade dos núcleos coloniais poloneses revelava a reprodução de padrões ancestrais de produção, sustentada pelas características culturais e ideológicas dos imigrantes poloneses (WACHOWICZ, 1981). Segundo Edward Tylor (apud TOMAZI, 1999) as ações humanas são resultantes da história cultural do sujeito, e se revelam não só pelos rituais, mitos, lendas ou estórias, mas por meio de crenças, objetos, cores, costumes e tradições das pessoas. Para Woortmann \& Woortmann (1997), cada cultura opera procedimentos técnicos, formas de saber e construções simbólicas específicas na transmissão do saber para o processo de trabalho e vida. Vale ressaltar o caráter dinâmico da cultura e dos costumes, que são flexíveis e dialógicos nas comunidades e entre os grupos, permitindo o remodelamento da formação dos hábitos (THOMPSON, 2005).

A cultura é herança transmitida de uma geração a outra, e os membros de uma comunidade compartilham códigos de comunicação. Uma vez que possuem hábitos cotidianos similares, os grupos têm em comum um estoque de técnicas de produção e de procedimentos de regulação social que asseguram a sobrevivência e a reprodução das comunidades. Ao comungar os mesmos valores, justificados por uma filosofia, uma ideologia ou religião compartilhadas, alimentam uma identidade cultural (CLAVAL, 2001, p. 63).

Nas práticas e vivências das famílias da Colônia Dom Pedro II pode-se observar características culturais e tradições que se perpetuaram pelo modo de vida, trabalho, jeito de ser das pessoas, danças populares, folclore, canto, 
versos, música, manutenção de expressões da língua falada e escrita, culinária, artesanato de flores de papel, festas, atividades religiosas, e arquitetura das casas. Há modos de fazer particulares que os definem como "poloneses" (SIKORA, 1997/2008).

A mulher polonesa no núcleo familiar assumia uma dinâmica de reprodução dos padrões culturais, cujo sistema de manutenção dos valores culturais da família tradicional, se constituía num conjunto de responsabilidades como a maternidade, preservação dos costumes, das tradições, religiosidade, o moral, o trabalho doméstico e agrícola. Na família, a mulher encontrava o ambiente em que se centrava o poder e a tomada de decisões. Contudo, ao mesmo tempo, havia o estímulo aos valores afetivos, morais e materiais necessários para o desenvolvimento e o bem estar das pessoas. Sendo o centro da vida social, responsável pela formação do desenvolvimento da personalidade e caráter dos seus membros, a mulher assumia 0 seu papel de transmissora de valores culturais e de manutenção da moral.

A noção de família define-se, assim, em torno de um eixo
moral. Suas fronteiras sociológicas são traçadas a partir
de um princípio de obrigação moral, que fundamenta
a família, estruturando suas relações. Dispõem-se às obri-
gações morais, e é o que define a pertinência ao grupo
familiar (SARTI 1996, p. 63).

O cotidiano da mulher polonesa reduzia-se às atividades que eram feitas em casa, na lavoura e com os familiares. Suas "obrigações" se desdobravam em múltiplos papéis: a mãe (maternidade), a educadora (a educação dos filhos), a doméstica (os serviços da casa), a cozinheira (o preparo das refeições), à professora (e o acompanhamento da educação formal e religiosa), a costureira (vestimentas), a lavadeira (higiene do vestuário) e a trabalhadora rural (plantio e colheita). Além disso, apesar da rigidez familiar, as mulheres imigrantes participavam de forma ativa nas decisões familiares.

[Na] família imigrante, sobretudo a colonial, a esposa estrangeira desempenha nela um papel ativo, participando das grandes decisões familiares, dos trabalhos no campo, do cuidado doméstico, do tratamento de animais de pequeno porte e cultivo da horta. A ela cabe, portanto, a direção da casa e toda a responsabilidade que daí advém (TRINDADE, 1992).

Desde os primórdios da imigração e ainda no decorrer das primeiras décadas do século XX, o trabalho da mulher era intenso e demandava esforço, sobretudo porque muitas comunidades não usufruíam os benefícios da energia elétrica, e, muitas vezes, as áreas eram desprovidas de recursos de primeira necessidade. Não havia o conforto das redes de água, dos combustíveis fósseis para mover veículos, máquinas e fogões, da energia para fazer funcionar aparelhos eletrodomésticos e de comunicação.

As comunidades rurais recebiam pouca atenção das municipalidades, em especial aquelas formadas por imigrantes. Mas, por outro lado, o 
Paraná era um estado brasileiro que não tinha uma infraestrutura viária e de energia de grande porte até os anos 1960. Foi no governo de Ney Aminthas de Barros Braga que se elaborou um plano de investimentos para a criação da Companhia de Energia Elétrica e a empresa de água e saneamento - SANEPAR. A energia elétrica chegou à Colônia Dom Pedro II no final da década de 1960, sobretudo porque a comunidade estava instalada muito próxima da capital do Estado, Curitiba.

Em 1958, Ney Braga candidatou-se e foi eleito para a Câmara Federal e em 1960 assumiu o governo do Paraná. Em nível estadual, ele deu continuidade ao Plano de Desenvolvimento do Paraná, iniciado com Oliveira Franco e seguido por Moysés Lupion, o PLADEP. [...] Oferecer os requisitos mínimos de infraestrutura para o setor industrial, formação de mão-de-obra especializada e utilização das rendas geradas na economia cafeeira na criação de um parque manufatureiro eram os três pontos primordiais, estabelecidos no PLADEP, à expansão socioeconômica do Estado (SILVA, 2011, p. 195-196).

As políticas municipais das cidades da região metropolitana de Curitiba eram deficitárias e atendiam pequenas parcelas das populações. Nas comunidades de imigrantes localizadas próximas a rios, os moradores faziam uso de técnicas para aproveitar a energia das águas para iluminar áreas, moer grãos, abastecer casas e animais. O represamento da água formava um volume suficiente para gerar energia (dínamo) e a abertura de poços era uma das alternativas para satisfazer necessidades de natureza hídrica.

\section{Trabalho e técnicas}

Segundo lamamoto (1999, p.64) "o trabalho é uma atividade humana exercida por sujeitos de classes [...] sujeitos que trabalham, cidadãos, portadores de uma herança cultural, de uma bagagem teórica e técnica, de valores ético-sociais". O trabalho doméstico e trabalho agrícola, entre os séculos XIX e XX, dependiam da força humana e da sua capacidade de fabricar instrumentos e aplicar técnicas agrícolas. Havia artefatos milenares e máquinas tipo engenhocas feitas de madeira e ferro. As técnicas de trabalho agrícola dependiam, por vezes, simultaneamente da energia animal e humana.

Muitos artefatos utilizados nas lavouras da Colônia D. Pedro II eram fabricados pelos próprios colonos, que conheciam as técnicas, e as utilizavam conforme as necessidades e o tipo do trabalho. Elas eram fundamentais para aperfeiçoar as atividades. O uso das carroças para transportar mercadorias predominou até 1948, quando apareceram as primeiras oportunidades para se adquirir veículos importados. Alguns colonos adquiriram o caminhão tipo furgão com arranque à manivela. Considerando que as técnicas fazem parte do processo social, corroboramos com Lima Filho \& Queluz (2005) ao considerar que elas não determinam por si só a realidade, mas elas fazem parte 
das interações, das práticas, saberes e conhecimentos dos grupos sociais.

A divisão de tarefas nos trabalhos envolvia questões de gênero. Em geral, nas comunidades de imigrantes, o homem se concentrava nas atividades agrícolas e criação de alguns animais de pequeno porte. Os demais membros da família o auxiliavam, inclusive da mulher. $\bigcirc$ trabalho agrícola exigia a preparação da terra, plantio, capina, pulverização e colheita carregada por carroças e armazenada em paiol da propriedade para consumo ou venda (BILINOSKI, 1997/2008).

Tanto a construção de casas, como instalação de moinhos de farinha movidos por água, fabricação de móveis e os vários instrumentos de trabaIho eram fabricados pelos próprios colonos. Só depois de 1940, foi instalada uma fábrica de móveis em um lugar chamado Timbotuva na cidade de Campo Largo-PR, e uma ferraria na cidade de Araucária -PR, especializada em fabricação de carroças. Na Colônia havia um ferreiro para trabalhos mais rudimentares (SIKORA, 1997/2008).

No sistema doméstico de produção, o tamanho da prole era fundamental para a sobrevivência dos colonos. Os filhos eram vistos como um investimento necessário, e até lucrativo, no sentido de que não se produzia somente para a própria subsistência, mas para criar excedentes. Os produtos hortifrutigranjeiros e laticínios eram levados aos mercados mais próximos das propriedades para comercialização (ANDREAZZA \& NADALIN, 1994, p.81).

Pelo trabalho, a mulher assumia as tarefas cotidianas familiares reproduzindo os saberes e costumes dos familiares e antepassados de forma cultural. O conhecimento geracional se realizava pela convivência cotidiana com os afazeres das avós, mães, tias, e depois, quando as filhas assumiam o seu papel de mulher casada, estes costumes tradicionais se transformavam em saberes e fazeres sociais.

Tanto as submissões como a obediência caracterizavam a sua dignidade e o seu papel perante a família e a sociedade. Suas tarefas seguiam uma rotina doméstica que, por vezes, demandavam força física considerada "exagerada" pela constituição do corpo feminino. Muitas delas podiam ser caracterizadas como pertencentes ao rol do "trabalho masculino".

o trabalho doméstico desenvolvia-se segundo uma normatização. As atividades cotidianas da casa incluíam aquelas características consideradas masculinas, uso da força física, sistematicidade, racionalização, incluindo também a implementação da lógica do trabalho mecânico. [...]. A construção da mulher como artefato doméstico não envolve unicamente a produção [...] mas a representação feminina no espaço doméstico (CARVALHO, 2005, p. 241).

De acordo com o tamanho da família as tarefas eram divididas com outras mulheres, avós, tias e jovens que ajudavam nos afazeres que se faziam necessários para a manutenção da casa numa família polonesa da Colônia. Na casa, elas cuidavam e arrumavam os jardins, os arredores da casa, plantavam flores em vasos e preparavam mudas. Com as frutas do pomar e os legumes da horta faziam compotas, licores, gengibirra, cervejas, picles, 
repolho azedo, marmelada e geleias. Sabiam tirar leite das vacas e transformá-lo em produtos laticínios como a manteiga, o queijo e o requeijão. Preparavam alimentos como bolos, bolachas decoradas pierogui, kuque, grochowinki, ponski, kluski, barzc, sonho e a broa integral assada na "pá" (VALENGA, 1997/2008).

Matavam animais para alimentação, sobretudo o porco e o boi, sempre observando as fases da lua, que deveria estar na minguante. Do porco, elas usavam a banha do toucinho, que era defumado e guardado em gamelas de madeira ou latas, fazia o salame e o chouriço com as vísceras. A carne do boi e do porco era cortada em pedaços miúdos, frita em banha para conservação em gamelas de madeira ou latas. Este tipo de preparo e acondicionamento das carnes garantia a alimentação da família por meses.

Lavavam roupas com sabão que fabricavam, remendavam e costuravam roupas, bordavam toalhas e tapetes com arremates de franjas. Elas confeccionavam cobertas e travesseiros aplicando as técnicas de retirar penas dos gansos na lua minguante.

As casas eram decoradas com flores de papel em especial para as festas religiosas (Kolendy) no Natal e (Wielkanoc) Páscoa. Preparavam cestas com alimentos e (pêssanki) ovos decorados que eram bentos pelos religiosos. Ajudavam nas festas de casamento, davam assistência nos partos, cuidava de doentes, velhos, e nos momentos da morte. Seguravam a vela benta na mão do agonizante e rezavam com ele, entregando a alma a Deus. Nos ritos funerários, participavam do preparo das pessoas da família (mulheres) no caixão, organizavam o velório e o enterro.

Liam livros que eram autorizados pelo Bispo sobre a vida de santos para os filhos e ensinavam a rezar e cantar, em especial cantos de missa, de natal, quaresma, páscoa e velórios (ALES, 1997/2008).

sábado era dia de limpar a casa. Varrer e passar escovão no assoalho, encerrar o chão, trocar as roupas de cama, arrumar o colchão de palha levantando-as, puxar várias latas de água do poço para lavar as roupas esfregando na tina à mão com sabão caseiro, coarar, enxaguar as brancas com anil e depois de secas recolher e passar a roupa a ferro de brasa e engomar as camisas de missa. Varrer os pátios e rastelar os gramados. Fazer requeijão... (VALENGA, 1997/2008).

É importante salientar que a mulher polonesa da Colônia Dom Pedro II seguiu esta rotina até a década de 1980, quando começaram a chegar os novos modos de vida difundidos pela sociedade da comunicação.

As mulheres embora frequentassem instituições de ensino, tinham pouca instrução, e eram semi-analfabetas para as letras, mas possuíam saberes e conhecimentos que não eram valorizados, como por exemplo, a manipulação das ervas medicinais. Aquelas que objetivavam seguir carreira profissional, o campo de trabalho estava, sobretudo no magistério, existente em colégios e conventos. Muitas jovens seguiam a vida religiosa desenvolvendo seus estudos em conventos de Freiras, com Irmãs Religiosas de diferentes congregações. 
Após a formação, quando voltavam para a Colônia Dom Pedro II, exerciam o trabalho em escolas da comunidade ou eram destinadas ao trabalho em colégios, escolas e igrejas católicas de outras comunidades poIonesas. Ter uma filha freira ou filho padre para a família polonesa representava status social e bênção divina, especial. Um familiar religioso, pelo seu conhecimento se constituía em um mediador entre a família e as diferentes instâncias sociais, governamentais, de tratamento de saúde ou na obtenção de outros benefícios.

Ao escolher em seguir a vida religiosa, sua profissão se traduzia em esperança de evolução familiar, social e de elevado respeito perante a igreja. Portanto a decisão da mulher em sair de casa para seguir a vida religiosa, como freira, deveria ser de convicção certeira, pois a sua desistência atingia a moral da família, resultava em murmúrios de fraqueza e de incertezas de sua idoneidade moral, discriminação social, como negação em seguir e servir a Deus pelo trabalho religioso.

Os pais normalmente davam aos filhos desejosos de seguir a vocação religiosa, a seguinte recomendação: "se escolher a vida religiosa, siga e não volte mais para casa, a não ser como Freira Irmã Religiosa" Ales, (1997/2008). Na Colônia Dom Pedro II, nas décadas entre 1940 a 1970, muitas famílias encaminharam seus filhos para vocações religiosas com formação de Padre ou Irmãs Religiosas. Embora a história da civilização das mulheres no contexto nacional e internacional estivesse presente nos ideais iluministas e progressistas do século XIX e XX, ainda estava longe a emancipação feminina e o abandono das crenças da tradição e da religião.

\section{A religião e o matrimônio}

Como destino, à mulher cabia a escolha do matrimônio ou da vida religiosa. Quando envelheciam solteiras, ficavam subordinadas ao domínio dos pais e irmãos casados com quem conviviam. Por vezes, eram exploradas, desprezadas e maltratadas. A "tia solteirona" devia cuidar de sobrinhos porque não tinha conseguido a felicidade do casamento.

Na unidade familiar polonesa a partir da mais tenra idade as crianças eram incentivadas a seguir a vida religiosa. Da mesma forma incorporavam as ideias de educação, subordinação, respeito e obediência aos mais veIhos, pais ou avós, reforçadas pelos conselhos e orientações das mães, avós, pelas aulas de ensino formal, pela catequese e homilias dominicais.

Às meninas, eram ensinados os princípios e valores necessários para que ela fosse boa mãe e esposa. No seu processo de ensino-aprendizagem, além das primeiras letras, ela desenvolvia habilidades e competências às prendas domésticas e tarefas na lavoura. A sexualidade se constituía em um tabu camuflado pelo pecado, fantasiada pelas tentações do demônio e ofensas a Deus. As orientações eram restritas e secretas e nem todas as mulheres recebiam conselhos antes matrimônio.

Todavia, no que dizia respeito à maternidade, ela era orientada para 
acreditar que ficar grávida e dar luz a uma criança era natural da constituição familiar e era um desígnio de Deus. Os filhos eram dádivas divinas que deveriam ser aceitas e mereciam agradecimento. Isto podia ser confirmado no livro sagrado. A narrativa bíblica, no livro de Gênesis, capítulo 3, versículo 16, quando a personagem Eva aceita a maçã da serpente, mostra como o Senhor Deus, reagiu ao seu ato de desobediência "multiplicarei sobremodo os sofrimentos da tua gravidez, em meio de dores darás à luz aos filhos; o teu desejo será para teu marido, e ele te governará" (ALMEIDA, 2012).

No período do namoro e noivado, as filhas viviam um ritual de orientação para o casamento que se constituía como parte da educação. As avós e mães pregavam a submissão e obediência ao futuro marido, tal qual elas se comportavam com os pais, para elas alcançassem a felicidade conjugal. Recebiam como ensinamento sobre a vida de casada, a fidelidade religiosa, os necessários cuidados com a casa, o compromisso com a alimentação e o preparo das refeições, e a confecção do enxoval, que era bordado (VALENGA, 1997/2008).

Para as horas das doenças e mal estar, elas aprendiam a preparar chás, a praticar as crenças em simpatias, benzimentos e encantamentos. As particularidades de uma boa esposa e uma boa mãe era bastante holística e estava sempre apoiada nos ensinamentos cristãos. O caráter divino da sua missão estava na submissão às regras da Colônia e na maternidade. "Todavia muitas das vezes embora tivesse que ser suportado o peso do seu trabalho apenas pela dependência econômica do marido, mesmo assim a mulher era tradicionalmente educada" Canezin (2004, p. 147), para suportar o sacrifício de sua missão perante a família, de submissão e obediência ao marido.

Sem outras perspectivas de vida, ou alternativas, assumia a vida matrimonial e familiar como um compromisso de honra, diante do juramento sagrado, oficializado perante Deus na Igreja, no dia do seu enlace, o qual era preservado para o todo sempre, a não ser que a morte deflagrasse algum dos cônjuges. Segundo a Bíblia Sagrada, Gênesis capítulo 2, versículo 18, a mulher foi criada para auxiliar o homem. O Senhor Deus concluiu que "não é bom que o homem esteja só, far-lhe-ei uma auxiliadora que lhe seja idônea" (ALMEIDA, 2012).

Na visão de Lopes Praça, (Castro, 2000) o discurso da lgreja com base nos princípios da religião, teve um papel de transformação dos fiéis homens e mulheres de todas as classes sociais. A mulher "influencia definitivamente o futuro da humanidade. Daí a importância da religião numa mudança redentora da mentalidade social no que concerne à mulher" (CASTRO, p. 25). No caso da Colônia, a religião teve um papel fundamental na regularização da moral pública e da moral da vida familiar.

As Igrejas cristãs no mundo ocidental incumbiram-se de manter esse statu quo ipsis litteris por milênios, reforçando, assim, o papel de sujeição da mulher ao homem. Prova dessa afirmação são os hábitos e comportamentos externos, como vestuário, etc., que insistem em mantê -los como se fossem capazes de imprimir virtude e san- 
tidade aos adeptos. A igreja católica nega à mulher a possibilidade de ingressar em seu quadro sacerdotal, ainda mantém o dogma da indissolubilidade do casamento, dizendo ser este um sacramento, e que representa a união de Cristo com a Igreja ... (CANEZIN, 2004, p. 144).

As mulheres evitavam a exposição em público, e ficavam isoladas do relacionamento social para preservação de sua imagem. "Não era permitido às jovens senhoras exibir-se em público, a menos que se tratasse de uma reunião religiosa ou de família, ou para fazer compras pessoais, ocasião em que eram sempre acompanhadas" (Idem, p. 145) pelo marido, mãe, avós ou filhas para evitar comentários.

\section{O domingo na Colônia}

As vivências entre as famílias da Colônia Dom Pedro II tinham características constituídas pela cultura e tradições da Polônia, as quais se originavam dos aprendizados religiosos. O elevado fervor de fé e devoção católica se reproduziu pelas gerações. Porém, para as mulheres, reinavam conflitos. Mesmo que aos domingos e dias santos elas tentassem interromper a rotina do trabalho para se dedicar a adoração a Deus e descansar, elas precisavam repetir as tarefas fundamentais na organização familiar: arrumar os quartos da casa, preparar as refeições para a família, tirar leite das vacas, tratar os animais domésticos, e arrumar as crianças para missa.

Aos domingos a mulher, o marido e os filhos saíam de carroça para a igreja assistir à missa. Depois, voltavam para casa para o almoço de domingo. Em geral, o cardápio era sopa de frango com macarrão caseiro, ou barzc, batata, arroz e peirogui com carne de frango ao molho de gado. Como sobremesa comiam frutas de conserva ou colhidas do pomar. Após o almoço o descanso se dava somente depois da organização da cozinha. Com o marido e filhos ouvia radio com músicas polonesas, passeava pelas roças, observava os cavalos pastarem, recebia visitas de familiares e compadrios, ou raramente visitava a família, fazia flores de papel, bordava e ou passeava no jardim (ALES, 1997/2008).

A mulher polonesa ao participar com a família das celebrações dominicais ou novenas durante a semana, configurava possibilidade de expansão da convivência social. Servia para professar sua fé demonstrando a fidelidade cristã pela assiduidade em frequentar a igreja e ao mesmo tempo realizava-se a socialização pelo encontro com outras pessoas, padres, Irmãs religiosas, parentes e amigos da comunidade.

O contato e a comunicação favorecia a manutenção e troca de informações sobre os acontecimentos locais, relacionados a dinâmica da vida familiar e social da Colônia polonesa, entre eles os boatos, fofocas e segredos. Também obtinha as informações do mundo, inclusive da Polônia, passadas mediante os "porta-vozes", padres da igreja. Assim, a participação 
das ações religiosas na Paróquia aos domingos, configurava um processo de socialização e ao mesmo tempo a solidificação dos laços familiares. Além das visitas feitas ou recebidas por amigos e familiares, havia as festas comemorativas religiosas e familiares como casamentos, batizados, aniversários, mutirões e funerais.

Tanto aos domingos como no decorrer da semana, o dia na Colônia Dom Pedro II, começava muito cedo. Após o dia de domingo, a semana iniciava com a retomada das responsabilidades domésticas, da família, da lavoura, da educação dos filhos em idade escolar e de catequese. Os filhos normalmente necessitavam se deslocar a longas distâncias a pé, para chegar a escola e à catequese na Colônia. Servia o café da manhã para as crianças, ajudava na arrumação, fazia o lanche e colocava na mochila costurada de tecido e encaminhava-os para a escola na Colônia Dom Pedro II.

A distancia da escola desagradava às crianças pela caminhada a pé. Para chegar mais rápido a opção era correr muitas vezes descalço, passar por atalhos, potreiros e roças, com ou sem companhia de amigos, com chuva, sol ou frio chegavam ao destino. As aulas eram em língua polonesa até 1920, e depois em português e polonês (SIKORA, 1997/2008).

\section{A longevidade}

A convivência em família, a solidariedade, reciprocidade e respeito se constituíam em valores de manutenção das tradições polonesas, incluindo também os idosos, para os quais a vida é retratada com base na história fundamentada nas vivências voltadas aos aspectos culturais e de sabedoria. Nas culturas antigas a pessoa velha era considerada como uma pessoa honrada. A mulher, em particular, segundo os textos bíblicos, precisa preservar todos os valores e princípios que havia cultivado na sua juventude e maturidade para poder retransmiti-los.

Nas cartas paulinas, no Novo Testamento, o apóstolo Tito exorta a função das mulheres idosas de ensinar às mais jovens a "serem prudentes, a amarem seus maridos, a amarem seus filhos; (2:4); a serem moderadas, castas, boas donas de casa, sujeitas a seus maridos, a fim de que a palavra de Deus não seja blasfemada. (2:5) (ALMEIDA, 2012).

A longevidade deste ponto de vista é considerada como período de acúmulo de saberes e conhecimentos, os quais podem ser repassados por meio de exemplos para gerações descendentes. Nas famílias polonesas quando em período de preparação para a vida matrimonial ou na escoIha de uma profissão, os jovens procuravam conselhos de familiares mais veIhos ou de autoridades da Comunidade. "Os Padres, Freiras, avós paternos, maternos, os padrinhos de batismo, de crisma tinham grande consideração pelos filhos das famílias polonesas pelos conselhos, orientações, e bênçãos designados" (NALEPA, 19972008).

Para Simone de Beauvoir, (1990), a velhice é um fenômeno histórico- 
social que retrata a vida fundamentada nas experiências e práticas de valores e princípios da cultura. A velhice é o estado maior de sabedoria devido ao privilégio de vivenciar a infância, a juventude, o matrimônio, o celibato, a maternidade, as amizades, a religião, a formação escolar e os contatos com outros locais, cidades e países. Então, "a velhice não poderia ser compreendida senão em sua totalidade; ela não é somente um fato biológico, mas também um fato cultural" (BEAUVOIR, 1990, p. 20).

A convivência e o respeito dispensado aos familiares mais velhos, avós e pais nas famílias da Colônia Dom Pedro II, os passeios, rezas, refeições, eram momentos de expressão de sentimentos e trocas de ideias sobre os costumes e tradições vividos no cotidiano, e de reforço de princípios por meio de conselhos "sábios" sobre o lar, o trabalho, e os plantios. Saberes religiosos, sobretudo crenças consideradas heréticas, também eram transmitidos.

Mesmo com as imposições e os julgamentos desfavoráveis da Igreja sobre o ocultismo, as mulheres, secretamente, faziam a passagem de ensinos metafísicos, fundamentados nas escolas esotéricas da Antiguidade (Egito, Babilônia e Grécia). Elas eram nomeadas feiticeiras (czarownice). Eram formas de libertação e expansão da consciência, sobre os mistérios do ser humano e do Universo, as quais se materializavam na feitura de benzimentos, superstições, encantamentos, simpatias e amuletos para combater doenças das pessoas e dos animais, e atrair prosperidade. Cita-se o caso da reza por intermédio da "Pedra de Calvário Woltront", um amuleto que ainda hoje algumas famílias possuem como relíquia (SIKORA, 1997/2008).

Havia casos em que os filhos residiam com os descendentes mais idosos, como por exemplo, os pais ou avós, e eles tinham o privilégio da convivência cotidiana para absorver ensinamentos sobre os antepassados, a vida, a cultura, e a religião. Vale lembrar que os idosos eram os representantes da sabedoria, e mereciam respeito de todos. O compromisso com a família era a garantia da alegria. Eles eram cuidados até terminarem suas missões terrenas, sendo sempre lembrados nos ritos religiosos, como celebrações dominicais, missas e visitação aos túmulos no cemitério.

Luiz Ales, quando entrevistado, fez depoimentos que confirmam este tipo de laços familiares, quando expressa seu prazer em trabalhar com a mãe na lavoura e ouvir as recomendações de seus pais como, por exemplo: zele e reze sempre pela sua família, respeite e obedeça aos ensinamentos divinos e alcançará a prosperidade. Segundo o entrevistado, os filhos que desrespeitam seus pais não são abençoados, vivem a infelicidade e a maldição na família. Ele faleceu em 2009 aos 86 anos, e seus conselhos, ensinamentos e sabedoria ecoam nas mentes de seus filhos, parentes e amigos (ALES, 1997/2008).

As virtudes e o respeito eram condições de harmonia na família, revigorados pela sabedoria dos mais velhos. Assim os saberes e o conhecimento cultural das tradições e costumes ancestrais poloneses, repassados de forma geracional, davam significados e valor étnico capazes de dar continuidade às tradições e culturas daquela Polônia que existia em suas mentes. A família 
assumia um papel fundamental perante a sociedade, e ela se multiplicava com a ajuda de todos, crianças, jovens, homens, mulheres, idosos e idosas. Culturalmente a mulher era também o centro do núcleo familiar, com responsabilidades de formação de homens e mulheres. Porém, muitos fatores como preconceitos, exploração e crenças impediam de fazer brilhar os seus valores.

\section{Considerações finais}

Apesar das mudanças significativas na condução da vida familiar, seja por causa das guerras, das imigrações, da economia industrial, e dos avanços tecnológicos, as famílias da Colônia Dom Pedro II (1876) conseguiram manter muitos valores cultivados em seu país até os anos 1990. Muitas foram as dificuldades enfrentadas por todos como a língua, o clima, as terras com matas, os poucos instrumentos de trabalho e a falta de representação junto aos órgãos de defesa públicos e da imigração.

A mulher imigrante polonesa se manteve no seio familiar, assumindo as responsabilidades perante o matrimônio, a família, os afazeres domésticos e as atividades agrícolas, no modelo de família tradicional romana, influenciada pelos ensinamentos da igreja católica. Viveu sob "aparente", conformação de submissão imposta pelas leis, pela religião e pelos aspectos culturais de uma comunidade tradicional patriarcal fechada.

A própria legislação brasileira a desfavorecia para cogitar qualquer mudança na sua posição familiar, e ela esclarecia sobre os papéis dos cônjuges no consórcio conjugal: o marido era "dono da propriedade" e a mulher era a "dona do lar". Também postulava a discriminação da mulher em sua hereditariedade, pois os pais podiam deserdar a filha desonesta, ou o marido podia devolver aos pais a filha que não fosse virgem no ato do casamento.

Após a Segunda Guerra Mundial, quando as mulheres americanas começaram a sair de casa para trabalhar, pois os homens estavam nas batalhas, as lutas feministas e os movimentos sociais se voltaram para a reivindicação de direitos de igualdade. A sociedade tradicional centrada na família patriarcal foi sendo minada pelas novas legislações nacionais, como por exemplo, a Lei 4.121/62 que criou o Estatuto da Mulher Casada e a Lei 6.515/77 que viabilizou a instituição do Divórcio, a Constituição Federal de 1988, e o Código Civil de 2002.

Estas aberturas para a emancipação da mulher polonesa foram chegando pouco a pouco na Colônia Dom Pedro ll. A Igreja toma a frente destes movimentos, e promove Congressos Eucarísticos e Missões Católicas, movimentos, grupos de reflexão da Teologia da Libertação e círculos de Nossa Senhora. O objetivo era manter viva a reflexão da família sem perder os laços com as crenças e tradições do passado.

Muito importante no processo de mudança foi também a vinda da energia elétrica na Colônia, que possibilitou a entrada nas casas de eletro- 
domésticos e da televisão, a qual se tornou imediatamente uma nova preocupação para os religiosos, que previam mudanças comportamentais e de valores com os programas televisivos. Ainda perdurava, nos anos 1960, a crença que o progresso poderia trazer juntamente o bem e o mal.

Embora a mulher polonesa tivesse grande influência na formação sociofamiliar, e exercesse diferentes papéis, ela não deixou de restringir seus "voos" de liberdade, sobretudo, para contestar o sistema patriarcal. Ela continua se dedicando ao trabalho, à família e cultivando a religião e as crenças. Seus papéis como mãe, trabalhadora rural, dona de casa continuam no cenário da Colônia, porém a modernidade a tem ajudado a redefinir suas formas de existência na sociedade liberal.

\section{Referências}

ALMEIDA, João Ferreira. Bíblia Sagrada. Edição revisada e atualizada. Disponível em: <http://biblia.com.br/joaoferreiraalmeidarevistaatualizada/genesis/gn-capitulo-3/>. Acesso em: 20 mai. 2012.

ANDREAZZA, Maria Luiza \& NADALIN, Sérgio $O$. O cenário da colonização no Brasil Meridional e a família imigrante. Revista Brasileira de Estudos de População. Campinas: ABEP, v.11, n.1, 1994.

BARROS, Sérgio Resende. Matrimônio e patrimônio. Revista Brasileira de Direito de Família. Porto Alegre: n. 8, jan./mar., 2001, p. 5-12.

BEAUVOIR, Simone de. A velhice. Rio de Janeiro: Nova Fronteira, 1990.

BOSCHILIA, Roseli. Representações da masculinidade nas práticas escolares. In: MATOS, M. I. S. et al. (orgs.). Sonhos e identidades. São Paulo: Núcleo de Estudos de Mulheres/PUC-SP e CNPq, 2004. (e-book).

BOSCHILIA, Roseli (org). Reconstruindo memórias: os poloneses do Santo Inácio. Curitiba: Univ. Tuiuti do Paraná, 2004. 135 p.

BRASIL. Constituição da República Federativa do Brasil. 1988. Disponível em: <http://www.planalto.gov.br/ccivil_03/constituicao/constitui\%C3\%A7ao. htm> Acesso em: 20 nov. 2011.

BRASIL. Lei $n^{\circ} 3.071 .1^{\circ}$ de janeiro de 1916. Código Civil dos Estados Unidos do Brasil. Disponível em:<http://www.planalto.gov.br/ccivil_03/leis/L3071.htm>. Acesso em 28 mai. 2012.

CANEZIN, Claudete Carvalho. A mulher e o casamento: da submissão à emancipação. Revista Jurídica Cesumar. Maringá-PR, v.4, n. 1, 2004. Disponível em: < http://www.cesumar.br/pesquisa/periodicos/index.php/revjuridica/issue/view/23>. Acesso em 12 set.2011.

CARVALHO, Vânia Carneiro. Gênero e artefato. São Paulo: Edusp, 2008.

CASTRO, Helena de Fátima Gonçalves de. Emancipação da mulher e rege- 
neração social no século XIX, segundo Lopes Praça. Faculdade de Letras da Universidade de Lisboa. Dissertação de mestrado. 2000. Disponível em < http://criticanarede.com/teses/lopespraca.pdf >. Acesso em 12 set. 2011.

CLAVAL, Paul. A geografia cultural. Florianópolis: Editora da UFSC, 2001.

DALL' ALBA, Felipe Camilo. Os três pilares do Código Civil de 1916: a família, a propriedade e o contrato. Disponível em:<http://tex.pro.br/tex/ listagem-de-artigos/239-artigos-set-2004/4973-os-tres-pilares-do-codigo-civilde-1916-a-familia-a-propriedade-e-o-contrato>. Acesso em 28 mai. 2012.

DEL PRIORE, Mary. A mulher na história do Brasil: raízes históricas do machismo brasileiro, a mulher no imaginário social, "lugar de mulher é na história". São Paulo: Contexto, 1989.

GALANO, Mônica Haydée. Família e história: a história da família. In: CERVENY, Ceneide Maria de Oliveira (org.). Família e... São Paulo: Casa do Psicólogo, 2006.

IAMAMOTO, Marilda. V. O Serviço Social na Contemporaneidade: trabalho e formação profissional. São Paulo: Cortez Editora, 1999.

LIMA FILHO, Domingos Leite; QUELUZ, Gilson. Leandro. A tecnologia e a educação tecnológica: elementos para uma sistematização conceitual. Belo Horizonte: v.10, n.1, p.19-28, 2005.

MIOTO, Regina Célia Tamaso. Família e Serviço Social: contribuições para o debate. Revista Serviço Social e Sociedade. São Paulo: Cortez Editora, ano XVIII, n. 55, nov. /fev. 1997, p. 120-135.

MIOTO, Regina Célia Tamaso. A centralidade da família na Política de Assistência Social: contribuições para o debate. Revista Políticas Públicas. São Luis: EDUFMA, v. 8, n. 1, jan. / jun. 2004.

MONTEIRO, Washington de Barros. Curso de direito civil. São Paulo: Saraiva, 2001. 2V.

PEREIRA, Rodrigo da Cunha et al. Direito de família contemporâneo. Belo Horizonte: Del Rey, 1997.

RAUPP, Renata Gomes. A construção do novo paradigma jurídico-familiar na ordem constitucional de 1988. Florianópolis: Universidade Federal de Santa Catarina, 1996. Dissertação de mestrado. 1996.

SAMARA, Eni de Mesquita. A família brasileira. São Paulo: Brasiliense, 1983.

SARTI, Cynthia Andersen. A família como espelho. São Paulo: Autores. Associados, Campinas, 1996.

SILVA, Maclovia Corrêa. O plano de urbanização de Curitiba - 1943-1963 -e a valorização imobiliária. São Paulo, Blucher Acadêmico, 2011.

THOMPSON, Edward Palmer. Costumes em Comum. Estudos Sobre a Cultura Popular Tradicional. São Paulo: Companhia das Letras, 2005. 
TOMAZI, Nelson Dacio. Iniciação à Sociologia. São Paulo: Atual, 1999

TRINDADE, E. M. de Castro. Clotildes ou Marias: Mulheres de Curitiba na Primeira República. São Paulo. Universidade de São Paulo: 1992. Tese de Doutorado.

WACHOWICZ, Ruy C. O camponês polonês no Brasil. Fundação Cultural, Casa Romário Martins, Curitiba, 1981.

WACHOWICZ, Ruy. Órleans: um século de subsistência. Curitiba: Paiol, Fundação Cultural de Curitiba-PR, 1976.

WOORTMAN, Ellen; WOORTMANN, Klaas. O trabalho da terra: a lógica e a simbólica da lavoura camponesa. Brasília: Editora da UNB, 1997.

\section{ENTREVISTAS}

ALES, Luiz. Entrevista concedida à pesquisadora Mafalda Sikora em 1997 e em 2008.

BILINOSKI, Estanislau. Entrevista concedida à pesquisadora Mafalda Sikora em 1997 e em 2008.

SIKORA, Miguel. Entrevista concedida à pesquisadora Mafalda Sikora em 1997 e em 2008.

VALENGA, Maria. Entrevista concedida à pesquisadora Mafalda Sikora em 1997 e em 2008.

NALEPA, Vitória. Entrevista concedida à pesquisadora Mafalda Sikora em 1997 e em 2008. 